NBER WORKING PAPER SERIES

DID HENRY FORD

PAY EFFICIENCY WAGES?

\author{
Daniel M. G. Raff \\ Lawrence $H$. Summers
}

Working Paper No. 2101

NATIONAL BUREAU OF ECONOMIC RESEARCH 1050 Massachusetts Avenue

Cambridge, MA 02138

December 1986

This paper represents a drastic revision of an earlier paper by the second author having the same title. We are grateful to Anne Piehl for her very capable research assistance and to David Crippen, Curator of Automobile History at the Ford Archives. This research was supported by the NSF and the Sloan Foundation. The data underlying the regressions are available on request. The research reported here is part of the NBER's research programs in Productivity and Economic Fluctuations. Any opinions expressed are those of the authors and not those of the National Bureau of Economic Research. 
NBER Working Paper \#2101

December 1986

Did Henry Ford Pay Efficiency Wages?

\section{ABSTRACT}

This paper examines Henry Ford's introduction of the five-dollar day in 1914 in an effort to evaluate the relevance of efficiency wage theories of wage and employment determination. Our general conclusion is that the Ford experience is strongly supportive of the relevance of these theories. Ford's decision to dramatically increase wages is most plausibly portrayed as the consequence of labor problems of the kind stressed by efficiency wage theorists. The structure of the five dollar day program is consistent with the predictions of efficiency wage theories. There is vivid evidence that the five-dollar day resulted in substantial queues for Ford jobs. Finally, significant increases in productivity and profits at Ford accompanied the introduction of the five-dollar day.

Daniel M.G. Raff Harvard Business School Harvard University Boston, MA 02135
Lawrence H. Summers Department of Economics Harvard University Cambridge, MA 02138 
Economists understand well how a perfectly competitive labor market without information problems would function. Flexible wages would clear labor markets and eliminate involuntary unemployment. The wages of workers of a given productivity would be equalized and would not depend on age, race, sex or location of employment. Wage differentials for workers with the same productivity could not persist because employers would hire only the low wage workers, creating excess supply of high wage workers. Yet wage determination does not seem to work this way in practice. Involuntary unemployment is observed frequently, and it has proven extremely difficult to account for the extent of age-, race-, sex-, firm size-, and industryrelated wage differentials by pointing to differences in productivity or to relative disamenities in the work itself. This is not just an artifact of union activity: even in labor markets where labor is unorganized, involuntary unemployment and wage differentials appear pervasive.

These realities have led to the development of efficiency wage theories along lines recently surveyed by Stiglitz (1984) and Katz (1986). These theories have in common the implication that over some range a firm can Increase its profits by raising the wage it pays its workers to some level above the market-clearing one. A variety of mechanisms, turning on the role wage increases might play in eliciting effort, reducing turnover, attracting better workers, and in improving morale, have been suggested to explain why profits might be an increasing function of wages. Some such mechanism must be central to any neoclassical explanation of these facts. So long as we assume that firms maximize profits, the only way to explain why firms do not lower their wages in the face of excess supply of labor is to postulate that it would lower their profits to do so.

This tautological argument in support of efficiency wage theories is not especially satisfying in several respects. First, it rests on the demonstration of 
wage differentials which cannot be explained by differences in ability. Since individual productivity cannot be observed directly, such an inference is inherently problematic. Second, it provides no indication of which efficiency wage theory explains the payment of supra-competitive wages and therefore gives no explanation of why firms fail to lower their wages in the face of an excess supply of labor. 1 Third, as an argument by elimination, it does not provide any direct support for efficiency wage theories as opposed to some as yet unspecified alternative line of explanation for wage differentials.

For all these reasons, one would like to see more direct tests of particular efficiency wage theories or, more generally, of alternative explanations for wage differentials. Such tests are difficult to construct. The very impediments to evaluating workers' ability, motivation and stability which might lead employers to pay efficiency wages make conventional testing of efficiency wage theories difficult. If the information needed to test these theories were available, there might be no need to pay efficiency wages. Econometric tests of efficiency wage theories also face the problem that variations in wages across firms or workers are unlikely to be exogenous, complicating considerably the problem of identification. It is thus not surprising that fully satisfactory tests of efficiency wage models have yet to be undertaken. 2

This paper considers a famous historical episode with obvious bearing on the relevance of efficiency wage theories. In January of 1914, Henry Ford instituted a \$5-a-day minimum wage in his automobile factory. This doubled the pay of most of his workers. Ford himself, in a subsequent commentary on this epochal event, observed that

There was...no charity in any way involved... We wanted to pay these wages so

1 Throughout this paper, we will use the phrases "supra-competitive wages" and "wages above the market-clearing level" interchangeably.

2 Two recent but not entirely satisfactory attempts are Dickens and Katz (1986) and Krueger and Summers (1986). 
that the business would be on a lasting foundation. We were building for the future. A low wage business is always insecure... The payment of five dollars a day $f_{\beta} r$ an eight hour day was one of the finest cost cutting moves we ever made.

Ford (or his ghostwriter) seems to be suggesting here that efficiency wage concerns both motivated the five-dollar day and were validated by its aftermath.

Given the general difficulties involved in econometrically testing these theories, a qualitative approach to a specific, narrowly defined episode seems to hold some promise. By focusing on a single event and a single company, we are able to avoid the blurring of important distinctions within firms and industries which afflicts other recent studies and to examine complexities that are inevitably obscured in situations in which only summary statistics are available. We are greatly aided in this by the fact that an extraordinary amount is known (or inferrable from materials in archives) about production in this particular firm and about not only the actions of the company and their consequences but also about the decision-makers' motivations. Moreover, the Ford episode involves a spectacular rise in workers' income. If evidence of productivity enhancing effects cannot be found in this setting, with the take-home pay more than doubled, it is implausible that such effects could represent an Important aspect of the much smaller differentials generally observed in contemporary labor markets.

We begin by describing the developments at Ford and elsewhere which preceded the introduction of the five-dollar day. Our focus here is on whether the dramatic wage increase offered by Ford might have been motivated by a desire to improve profits through influencing worker behavior along the lines suggested by some efficiency wage theories. Next we describe the five-dollar day program--payouts and assoclated rules and institutions--in some detail. Here the goal is to draw inferences about intent from the structure of the program put in place. Finally, we turn to an evaluation of the actual effects of the five-dollar day, concentrating 
on the two questions suggested by contemporary efficiency wage theories. First, did the program in fact generate queues of workers? (Alternately, was Ford simply paying the wage necessary to attract labor of the desired quality to his plant?) Second, did the wage increase confer productivity benefits through any of the channels suggested by efficiency wage theorists--increased worker discipline, better selection of workers, reduced turnover or improved worker morale?

Our general conclusion is that the Ford experience supports the relevance of efficiency wage theories. Ford's decision to dramatically increase wages is most plausibly portrayed as the consequence of labor problems of the kind stressed by efficiency wage theorists. The structure of the five-dollar day program is consistent with the predictions of efficiency wage theories. There is vivid evidence that the five dollar day resulted in substantial queues for Ford jobs. Finally, significant increases in productivity and profits at Ford accompanied the introduction of the five dollar day.

While the Ford experience is generally consistent with efficiency wage theories, it is not easy to explain the large productivity improvements that occurred in the Ford plant wholly in terms of the mechanisms that have been stressed in the recent efficiency wage literature. Jobs were sufficiently menial that it is unlikely that high turnover was extremely costly or that worker selection effects were important. While improved productivity was associated with notable increases in effort, the increases in effort probably were easily monitored, contrary to the implication of theories based on the difficulty of perfect monitoring. Ford's wage setting policies probably involved a substantial component of rent-sharing, that went on in a context in which history and the beliefs of the employed workers mattered. To fully explain the Ford experience, richer theories which treat the details of the production technology in more detail and assign a more active role to 
incumbent workers in the wage setting process appear to be required. Such ideas are developed and explored in Raff (1986), a monograph which draws on extensive archival research to subject such an account, along with those considered here, to detailed analysis.

This paper is organized as follows. Section I briefly describes some of the events leading up to the introduction of the five-dollar day and puts them in the context of efficiency wage theory. Section II describes the measure itself in a similar way. Section III examines the extent to which the wage proved to exceed the equilibrium wage needed to attract a sufficient supply of labor to the Ford plant. Section IV examines the impact of the five-dollar day on profits and productivity. Section $V$ concludes the paper by discussing the implications of the results for efficiency wage theorfes and more generally for the economic analysis of labor markets.

\section{THE PERIOD PRECEDING THE FIVE DOLIAR DAY}

This section describes the events preceding Ford's introduction of the fivedollar day in January 1914. It draws heavily, as all subsequent treatments must, on Nevins' authorized company biography, Ford: The Tines, the Man, and the Company (1954) and on Meyer's careful if less wide-ranging study, The Five Dollar Day (1981). But it puts the basic material, and the gleanings of our own research, in a very different light, for neither Nevins nor Meyer writes with an economist's perspective. Nevins portrays Ford as idealistically attempting to do the right thing for his workers. Meyer sees matters in terms of a struggle for control of the working environment between Ford and his workers. The question of whether Ford was trying to maximize something other than profits is skirted by both authors. More generally, these authors--Iike the other historians and more popular writers who 
have written about the five dollar day--are more concerned with describing what happened than with analyzing in any systematic context the reasons behind it.

\section{General Background}

The Ford Motor Company was founded in 1903 and remained quite small for the next five years. By 1908 it had only 450 employees and produced just 10,607 automobiles. At this point Ford's share of the automobile market was 9.8 percent. A large fraction of the company's employees were skilled craftsmen--on one description the early Ford factory was "a congeries of craftsmen's shops rather than an integrated plant". ${ }^{4}$ By 1910 roughly two-thirds of the workforce were either foremen or mechanics rated either "highly skilled" or "skilled". 5 Such workers exercised, as they would have done most everywhere in American industry of the day, "broad discretion in the direction of their own work and that of their helpers. They often hired and fired their own helpers and paid the latter some fixed proportion of their earnings. " 6

The reasons Ford employment had this character are easy to identify. Ford was not manufacturing, but merely assembling, cars. The parts were produced by outside machine shops and were not made to any particularly high tolerance. A great deal of shaping and fitting was required to get them together properly. This called for industrial skills, skills relying on the judgment of the metalworking craftsman.

The 1908-1914 period saw drastic changes in the method and scale of production at Ford. Early in 1908 Ford settled on the design of the Model $T$ and the idea of producing nothing else. Ford's philosophy was clear. As he subsequently stated:

The way to make automobiles is to make one automobile like another automobile, to make them all alike, to make them come through the factory just like alike,

4 Meyer (1981), p. 15.

5 Meyer (1981), p.48.

6 Montgomery (1979), p. 11. 
just like one pin is like another pin when it comes from the pin factgry and one match is like another match when it comes from the match factory.

Ford wanted to do this by having the parts made to sufficiently high tolerances that skilled fitting would no longer be required. The production process was also simplified by redesigning the workshop to minimize unnecessary movement of workmen and parts. In general, the work was brought to the workers, and the workers' tasks came to involve less and less judgment and discretion. All of this enabled production on an unprecedented scale. ${ }^{8}$ By 1913, just before the introduction of the five-dollar day, the number of workers had increased to 14,000 . Output had risen twenty-five fold over the preceding five years to 248,307 cars. ane sees something of the impression this made on contemporaries in the vivid description of one journalist: "One day's shipment alone leaving the factory a half a mile apart, would reach from Detroit to New York City." 9 That day's shipment was many times the daily, and in some cases even monthly, output of any of Ford's competitors. They still produced cars in the old-fashioned way.

These changes in production methods, capped by the introduction of the assembly line, were associated with a major change in the character of the Ford workforce. By 1914 three quarters of it was foreign-born and more than half were recent immigrants from the unindustrialized regions of southern and eastern Europe. There is a great deal of evidence that the jobs they filled could be learned extremely

7 Chandler, ed. (1964), p. 28.

8 The first moving assembly lines were installed in April, 1913; and that production technology first came to final chassis assembly in October. These were the dramatic events. But we should be clear, as many who write on this subject are not, that as of late 1913 most of the Ford production workforce was not working on an assembly line. Nonetheless, the force of these routinizing methods was pervasive by then. Demands for component parts and sub-assemblies were more and more driven by the demands of the line. And machining tasks themselves were more and more being carried out with single-purpose rather than general-purpose tools, offering less and less scope for metalworking skills and less and less scope for machinists to control their time. (It was this development--more broadly, the so-called American system of production--and not assembly lines in themselves which made production on a very large scale possible. See Hounshell (1984), passim.

9 Colvin (1913), p. 758. 
easily. Meyer quotes reports (from a later period but essentially the same production process) suggesting that fobs could swiftly be learned by a man in off the street. The following report of a Yale engineering student who worked for Ford during a summer is typical.

Division of labor has been carried on to such a point that an overwhelming majority of the jobs consist of a very few simple operations. In most cases a complete mastery of the movements does not take more than from five to ten minutes. All the training that a man receives in connection with his job consists of one or two demonstrations by the foreman or the workman who has been doing that job. After these demonstrations he is considered a fully qualified 'production man'. All that he has to do now is to automatize these few operations so that speed may rapidly be increased.

The dramatic evolution in production technology changed fundamentally the Iffe of the working man. As tasks came to be divided more and more finely and to become more and more routinized, work became more menial. At the same time, the need for workers to be in lockstep to make the assembly line work smoothly increased the pressure on workers. The issue here is centralized setting of the pace of work and, more generally, centralized control of effort requirements. Single purpose machine tools and the moving assembly line both offered means for the company to fully utilize the labor time it purchased in the same way its mechanics and repair shops allowed it to fully utilize its machines. ${ }^{11}$ Meyer quotes another Yale student on the immediate consequences thus.

You've got to work like hell in Ford's. From time you become a number in the morning until the bell rings for quitting time you have to keep at it. You can't let up. You've got to to get out the production and if you can't get it
out, you get out.

The effect of all this was well summed up by the Ford laborer who said "If I keep putting on Nut No.86 for about 86 more days, I will be Nut No. 86 in the Pontiac

10 Meyer (1981), p. 41. The period, we should note, was a later one but the technology and shopfloor methods were essentially unchanged. 11 Ford himself had long railed against the problem of soldiering i.e. output restriction, which he labelled as "the source of more than half the trouble in the world today". (Meyer (1981), p. 88). Commons (1923), p. 365, described the labor market behavior of such workers vividly when he wrote that "They are conducting a continuous unorganized strike." 
bughouse. " 13

While anecdotal evidence of worker dissatisfaction can be found almost anywhere, worker dissatisfaction at Ford took visible form. In 1913, annual turnover at the Ford plant reached 370 percent. Ford had to hire 50,448 men during the course of the year in order to maintain the average labor force at $13,623 .^{14} \mathrm{~A}$ company survey revealed that slightly more than 7,300 workers left the company in March, 1913. Of these about 18 percent were discharged, 11 percent quit formally, and 71 percent were so called "five day men" who had missed five work days in a row without excuse and so were simply deemed to have quit. The 370 percent was high even by the standards of the fluid Detroit labor market, in which turnover rates of 200 percent were quite common. 15 Contemporary experts on the problem of high turnover, notably Boyd Fisher (1917), regarded high turnover as being the result of a combination of factors including the arbitariness of some foremen, inequities in pay, and inadequacies in plant conditions. Some observers also blamed the problem on the monotony of workers' jobs.

At the same time that turnover became so alarming, Ford also faced an epidemic of absenteeism. In 1913, the company suffered a 10 percent daily absenteeism rate. (This meant that on the average day it was necessary to make use of 1300 or 1400 replacement workers each of whom was inexperienced at the specific task they were to perform.) Sumner slicher took the view that the worker simply needed a break from the rigors and routines of mechanized factory 1 ife. ${ }^{16}$ without formal vacations, he thought, the voluntary lay-off was the working class vacation.

Despite all this the company was flush. Ford's market niche had emerged as a near monopoly in the production of the relatively inexpensive cars selling for $\$ 600$

12 Meyer (1981), p. 44 .

13 Meyer (1981), p. 40 .

14 The figures come from Slichter (1921), p. 244. Other sources give slightly different ones, but to no different effect.

15 Slichter (1921), p. 33-34. 
or less: by 1913, the Model $T$ had a 96 percent market share in this field. During the five years preceding March 1, 1913, profits averaged 118 percent of tangible assets. During the year 1912 these profits had exceeded 132 percent. It is indicative of the demand for Ford cars that the company was able to price in such a way that it earned profits equal to 31 percent of sales. The profitability reflected in part the popularity of Ford cars and in part the efficiency of Ford production techniques.

Motivations for Making a Change in Compensation

The motivations for the decision to introduce the five dollar day package in January of 1914 are difficult to pin down. Ford's ghostwriters are certainly inconsistent regarding his intentions. ${ }^{17}$ But enough is known of the historical record to permit some inferences about Ford's intent.

The simplest explanation suggested by economic theory for why a firm would raise its wages sharply involve the possibility that it was unable to attract a sufficient quantity of labor of the desired quality. Inability to attract workers could result from either wages which were to low or uncompensated unpleasant aspects of jobs.

While Ford had substantial difficulty in retaining and eliciting effort from workers, it is very unlikely that Ford raised wages in January of 1914 because of difficulties getting enough workers to accept Ford Jobs. By 1913 the Iong employment line in front of the Ford plant had become, in the phrase of one contemporary observer, "one of sights to whet the curiosity of rubber neck

16 Silchter (1919), pp. 826-827.

17 Compare "If it is right for the manager of a business to try to make it pay a larger dividend, it is quite as right that he should try to make it pay higher wages... Such are the fundamental truths of wages. They are partnership distributions." (Ford (1922), p. 121.) with "I am not a reformer." (Ibid., p. 3.). 
tourists. "18 There is essentially no evidence that the company had any trouble with vacancies at the wages it was offering. Ford's labor problems in this sense transcended demand and supply. And beginning in the summer of 1913, the available supply of labor must have increased as the national economy in general and that of the Detroit hinterlands in particular suffered a significant downturn. Table 1 shows that the number of persons recelving special unemployment relief increased by about two thirds between the period July 1, 1912-June 30, 1913 and the analogous period the following year. It is thus not very plausible that labor shortages, to whatever extent they existed, were expected to be particularly acute during the winter of 1914.

Nor is it plausible that Ford chose to raise wages in order to attract more highly qualified workers. The whole of the technical change at Ford during this period was moving towards less skilled work. Other things equal, this would lead to a prediction that wages would fall not rise.

Ruling out these standard competitive explanations for a wage increase, we are left with two other possible explanations. Ford may have increased wages in an effort to raise productivity by reducing the turnover and absenteeism, or through getting directly at some morale problem. These are the canonical efficiency wage explanations for the decision to raise wages. Alternatively, he may have doubled wages for some personal reason--to be magnanimous or perhaps to become famous. There is evidence in the events leading up to the five-dollar day to support and to refute both interpretations.

It is clear that for some time prior to the introduction of the five dollar day in 1914, Ford management had been concerned about labor motivation and its consequences for productivity. Originally the company had had no particular policy or strategy for managing labor. John R. Lee, the first Ford personnel manager, 
TABLE 1

Poor Relief in Wayne County 1910-1915

\section{Period $^{1}$}

$$
\begin{aligned}
& 1910-1911 \\
& 1911-1912 \\
& 1912-1913 \\
& 1913-1914 \\
& 1914-1915 \\
& 1915-1916
\end{aligned}
$$

Persons Granted Relief

$$
\begin{gathered}
5,724 \\
5,768 \\
5,266 \\
8,932 \star \\
19,085 \star \star \\
9,047
\end{gathered}
$$

1 July of each year to June of following year.

* Nearly a $50 z$ increase

** The recession in full force

Source: Garrity, tabular appendices. 
later described the evolution of this state of affairs thus.

We began to realize something of the relative value of men mechanism and material, so to speak, and we confess that up to this time we believed that mechanism and material were of larger importance and that somehow or other the human element of pyr men were taken care of automatically and needed little or no consideration.

Lee went on recount an incident in which the output of a drop hammer operator fell off abruptly. Investigation revealed that his wife was very $i l l$ and that he was preoccupied with fears for her and worries about paying for the medical expenses being incurred. The company paid off the debts. The operator's productivity jumped back up again.

In the summer of 1913 Ford management asked Lee to undertake a study of the condition of labor at Ford, including the worrying turnover rates. Lee conducted an investigation, compared what he had found to what was to be seen in other contemporary plants, and issued a report. In it he said that the chief causes of dissatisfaction and unrest among the employees were as follows. 20

1. Too long hours. A man whose day is too long and whose work is exhausting will naturally be looking for another job.

2. Low wages. A man who feels that he is being underpaid will always be looking for a change in occupation.

3. Bad housing conditions, wrong home influences, domestic trouble, etc.

4. Unsanitary and other undesirable shop conditions.

5. Last and perhaps the most important cause of dissatisfaction is the unintelligent handing of the men on the part of the foremen and superintendants.

These points speak to the question of what lay behind the turnover. They are equally consistent with the view that turnover was a problem in itself and with the view that dissatisfaction in itself is what is to be feared. (That is, workers who may in the end leave but who for the moment are still on the shopfloor are in a position to slow down or otherwise interfere with the smooth operations.) Smooth co-ordination was becoming a more and more important component of the company's value-added, and collective acquiescence in shopfloor order and discipline was

$\overline{19 \text { Lee (1916), p. } 299 .}$ 
crucial in this.

Following Lee's study, on October 1,1913--three months prior to introduction of the five-dollar day--the company instituted a new personnel program with several elements designed to combat worker dissatisfaction. The first was an across the board wage increase of 15 percent. The second was a major effort to rationalize the pay structure. Previously there had been a wide variety of pay scales and pay rates. Individual foremen had had great discretion and essentially no supervision in these matters. Lee introduced a simpler and less easily abused "skill-wages" classification program in which workers' pay was determined on the basis of a relatively simple formula involving performance and seniority. Third, Lee eliminated foremen's ability to arbitrarily discharge workers by centralizing authority over hiring and firing in the Employment Department.

Evaluating this program is important in determining the motivation for the five-dollar day. To the extent that the reforms introduced in October were successful in solving the labor problems experienced within the Ford plant, it would be difficult to attribute the introduction of the five-dollar day to efficiency wage considerations. Alternatively, if the October program ameliorated but did not solve the labor problems at Ford, it is reasonable to see the five dollar day as just the second stage in a program (or the second battle in a campaign) directed at raising productivity. The limited information that is available supports the second interpretation. Lee, in describing the introduction of the five-dollar day treats the October and January reforms as aspects of a single program. ${ }^{21}$ Meyer concurs describing the program as "supplementing and extending" the earlier Ford reforms. 22 Strong evidence supporting this view is the observation that turnover declined in October when the reforms were introduced, but then appears to have risen sharply

20 See, e.g., Meyer (1981), p. 100.

21 Lee (1916), p. 301.

22 Meyer (1981), p. 108. 
again in November and December. 2324

An incident recounted by Nevins suggests that efficiency wage considerations may have played quite a conscious role in Ford's decision to raise wages: it establishes that Ford had had the possibility of a wage-productivity link quite explicitly expained to him. A close professional associate and personal friend of Ford's, Percival Perry, opened Ford's original British plant in Manchester. At first, Perry paid the then going wage of about one and a half pounds a week. But he then discovered that a wage of three pounds was required for a worker and his family to subsist adequately. He thereupon raised wages for all workers to three pounds a week and reaped substantial productivity benefits. When Ford visited England in 1912, Perry is known to have explained his "high wages and straight wages" plan in some detail. 25

We have been arguing, as we shall throughout this paper, as if it were certain that Ford was coping with whatever problems he saw in an effort to maximize profits. But it is possibile that Ford raised wages not in response to labor market problems but out of a desire to be magnanimous or to attract to attention to himself. This possibility must be taken seriously. Henry Ford owned 58.5 percent of the Ford Motor Company. There is little reason to expect that he would maximize company profits rather than his own utility. Ford spoke frequently and somewhat mystically

23 See Hounshell (1984), p. 258.

24 All of the available secondary source literature we have reviewed on the introduction of the five dollar day except Nevins draws the conclusion reached in the text. Nevins attributes the decision instead to "practical idealism," claiming that all the demands of efficiency engineering would have been met by Lee's October reforms. He draws his views in that passage (often, indeed, his sentences) from an undated memorandum now in the Ford Archives written by his research assistant, George Heliker, entitled "Labor in Detro1t 1900-1916". Neither Nevins nor Heliker address, or even allude to, any evidence about turnover in November and December. It is difficult to avoid the impression that they saw the monthly turnover figure for October, made up their minds, and gave the matter no further thought. But there are a number of reasons for believing that this is too simple an analysis and that the reports cited above are what one ought to have expected. See Raff (1986), Section 8.

25 Meyer (1981), p. 120. 
about the importance of sharing with the working man. Furthermore, the introduction of the five-dollar day brought him worldwide fame and reknown. ${ }^{26}$ There is no particular reason to think that Ford did not enjoy this acclaim.

On the other hand, he often seemed embarrassed that anyone might think him anything other than a hard-headed businessman. "I do not believe in charity, "he told a group of reporters at the New York Auto Show just after the announcement. 27 And the announcement itself, though proud and self-important in tone (see the text and accompanying footnote below), was hardly publicized at all. Ford and his business manager Couzens (also present at the announcement) knew very well that Reuters and the national wire services had resident correspondents in Detroit. Several Eastern newspapers had stringers. Representatives of auto and manufacturing trade journals were close at hand. Yet only reporters from the Detroit Free Press, Journal, and News were summoned to hear the great news. 28

While the desire for publicity, or an altruistic impulse, may have had something to do with Ford's decision, they seem unlikely to be the whole story. The five dollar day was projected to represent a $\$ 10$ million increase in the company's 1914 costs--an amount totalling about half the projected annual profits. It strains credulity to suggest that an expenditure of this magnitude could be explained wholly without recourse to tangible gains Ford might have expected to derive. Furthermore, and tellingly, there is no evidence of any serious objection from any of the minority shareholders. This group certainly included men who were willing to go to a law court if necessary to protect their minority interests against what they say as Ford's unreasonable caprice. ${ }^{29}$ In all likelihood, then, it seems safe to place

26 In seven days, for example, the New York press devoted more than fifty columns, mostly on front pages, to Ford. Lewis, who has surveyed that systematically, says the conservative New York Times ran 35 articles in 90 days. On the press coverage in general, see Lewis (1974), pp. 69-77.

27 See Detroit Free Press, January 9, 1914, p. 3.

28 Lewis, p. 69.

29 The case is discussed in Clark (1986), pp. 602-604. 
significant weight on the motivation stemming from Ford's view that he was in business to make money. The act is certainly consistent with that view and what Ford knew in early January.

\section{THE FIVE DOLIAR DAY PROGRAM ITSELF}

The new policy was announced with rhetorical flourishes but, as noted above, without much real publicity on January 5, 1914. The opening sentence set the tone: "The Ford Motor Company, the greatest and most successful in the world, will on January 12, inaugurate the greatest revolution in the matter of rewards for its workers ever known to the industrial world." The details were a reduction in the length of the working day from 9 to 8 hours and a raise in minimum daily pay from roughly $\$ 2.34$ to $\$ 5.00$ a day for those workers who were judged to qualify. The extra compensation paid to workers was labelled as profit sharing rather than wages. (We will come back to this point below.) At the same time, a number of the company's policles were altered. Some aspects of the package are difficult to tie to the efficiency wage theory literature, but many of the central features--written off by historians to Ford's (undoubted) personnel idiosyncrasies--are precisely the sort of features efficiency wage theory would lead one to expect.

There were a three main qualifications for eligibility. First, the five dollar day was extended only to men over the age of 22. Second, workers had to have worked with the company for six or more months to be eligible. ${ }^{30}$ Third, in the words of a 1914 Ford pamphlet, "A worker is only put on the list of profit sharers after he has been carefully looked up and the company is satisfied that he will not debauch the additional money he receives." ${ }^{31}$ A Sociological Department with a team of

30 This was, In fact, not brought in until the following autumn, but it thereafter remained as an integral part of the program roughly as long as the package recognizeably persisted. 
investigators and a considerable support staff--interpreters, drivers, cars, and so forth--was set up to carry out this last provision.

Paternalism is the most commonly advanced explanation for why women and young men were excluded from the Ford profit sharing program. The New York Times, after interviewing a number of Ford officials, reported on January 7 , that

The reason that women and girls in the employ of the Ford Motor Company will not share in the profit distribution announced by the company is because they are not, as a rule, the heads of families. In this respect, they are classed with the youths, the male employees of less that 22 years of age not [profit] sharing unless they happen to be married or supporting their mothers or families of brothers and sisters. It is understood that there are no women or girls in the Ford plant who come under this classification. If there should be, they undoubtedly would be taken care of.

A more cynical explanation consistent with the efficiency wage hypothesis is offered by Conot. He writes "Women did not work on the assembly line, and were not likely to drink and fail to show up for work. They did not jump from job to job. So there was no reason to include them." 32

The motivation for the six month qualifying period was thought to be even less clear. Unlike the exclusion of women, and the requirement of scrutiny by the Sociological Department, it receives virtually no attention in either contemporary or subsequent discussions of the five dollar day. Nevins does discuss it briefly, suggesting that the intent was to reward experience and reduce turnover as a matter of fairness and good business practice.

But some sort of tenure requirement for the receipt of the supra-competitive compensation is entirely consistent with the hypothesis that Ford was pursuing an efficiency wage strategy. Modern theoretical analyses of efficiency wage models

31 Meyer (1981) p.125

32 Conot (1974), p. 175. Nevins (1954), pp. 547-548, reports that Ford reluctantly under pressure from his colleagues allowed white collar workers to share in the five dollar day even though he did not see the need to raise their wages. ["He always figured you didn't need an office. ... Mr. Ford not being an office man, he didn't understand the routine." Brown Reniniscences, p. 118.] He did so on grounds of fairness. This type of behavior is consistent with the finding of Dickens and Katz (1986) that the interindustry wage structure is similar across occupations. 
based on either effort elicitation or turnover considerations suggest that firms will profit by tilting age-wage profiles relative to age-productivity profiles. ${ }^{33}$ The performance incentives of such tilting will be limited by employees' fear that if the tilt gets steep enough, the firm will be tempted to renege on its commitments. So the payment of efficiency wages is predicted to coincide with the limited use of bonding devices such as the granting of high wages only to experienced workers. Nevins specifically refers to fears that Ford would systematically fire workers before their six month probationary period ran out, but that Ford did not do this. It is thus plausible that such fears constrained Ford from imposing too long a probationary period, whatever his impulses about length may have been.

Most historical accounts of the five-dollar day devote a great deal of space to discussions of the role of the Sociological Department in regulating the habits of Ford workers. Both Lee and Ford themselves made much of it. They said that teaching their workers good living habits was a moral obligation on the company's part. The message was pointed and clear. Ford pamphlets told workers about the importance of taking baths, living in clean, airy, well-lighted, and uncrowded surroundings, and saving to buy one's own house. Excessive drinking, gambling, untidiness, consumption of unwholesome foods, and lack of enthusiasm for putting money regularly into a savings account were all potential grounds for exclusion from the profits. The 150 Sociological Department inspectors went to the homes of all workers and had to certify them before their occupants could receive profit sharing payments.

Those workers who were disqualified from profit sharing could get their full payments restored if they complied with the Sociological Department's instructions within thirty days. They could get partial payments if it took them longer to come

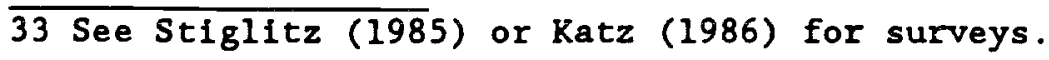


into compliance. Once a worker fell from grace, the profit shares were donated to charity until he returned--this was a show of good faith on the company's part. 34 In all of this there seems to be a posture of conscious education. And the company repeatedly said the interventions seemed to be welcome.

Accounts of the fraction of workers who actually received payments of at least five dollars a day in spite of these hurdles vary. Ford claimed that all but 1 percent received a payment of at least five dollars a day. ${ }^{35}$ Lee wrote in 1916 that 69 percent of the labor force qualified for profit sharing within the first six months of the plan, and that this figure rose to 87 percent after a year and 90 percent in mid-1916. These figures appear not to include workers who had not yet been at Ford for six months. Whichever figure is accepted, the overall percentage is large.

Two other elements of the Ford plan merit comment. First, Ford was at pains to avold the capricious discharge of workers but at the same time to maintain the threat that inefficient workers would be discharged. In January of 1914, the home office at Ford sent a letter to its branch offices instructing them to n... not keep anyone who has proven inefficient and has been given a fair trial in more than one capacity." 35 The foundering worker was to be given several chances to locate a job he could do well. But if none of these worked out, or if the worker came to seem simply a disciplinary problem, he was indeed to be let go. And there was public notice that this threat of discharge was not an empty one. Not long after the introduction of the five dollar day, nearly a thousand foreign workers did not turn up for work one day: they were all off in church celebrating the Greek or Russian orthodox Christmas. It was widely reported that they were summarily dismissed. ${ }^{36}$

\footnotetext{
34 See the exchange between Carmichael (1985) and Shapiro and Stiglitz (1985). 35 Meyer (1981) p.119

36 According to Motor Age magazine, the men were sent home for a day (drunk) but not dismissed. The point remains (drunkenness or no), as the threat was made quite clear.
} 
The strategy of trying to avoid capricious firings by stabilizing employment while at the same time threating to punish genuine shirkers with discharge, is exactly the one predicted by effort elicitation versions of efficiency wage theories. 37

Second, Ford executives laid considerable stress on the fact that it was a profit-sharing rather than a wage-increasing plan. ${ }^{38}$ This was intended to convey a notion that the extra payments were gifts to workers rather than payments they had a right to expect. 39 The fact that the profits were being shared with workers was said to be a justification for the company's conditioning payments on workers' spending their salaries wisely. Labelling the payments profit sharing also made it clear that the company would not feel bound, and certainly could not be held to have promised, to continue the income stream if its own fortunes sagged. Indeed, in its infancy the plan was labelled as an experiment to which the company was only bound for a year.

This discussion of Ford's five dollar day program gives a picture broadly consistent with the conclusions reached from our review of its pre-history. Whether or not the Ford wage increases were given for reasons like those suggested by efficiency wage theories, they provide a natural testing ground for these theories. We therefore turn in the next two sections to events occurring in the aftermath of the introduction of the five-dollar day.

III. WERE THE NEW FORD WAGES COMPETITIVE?

A hallmark of efficiency wage theories is their implication that some firms

37 As Bulow and Summers (1986), emphasize these the possibility of an arbitrary termination of employment reduce's a workers horizon and therefore makes holding his job less valuable and therefore encourages shirking.

38 They were to lay less stress on this as time passed and profits fluctuated.

39 Perhaps this should be interpreted as an instance of Akerlof's gift exchange 
choose to pay a wage greater than necessary to attract labor of the quality they desire. 40 since firms paying efficiency wages pay workers more than their opportunity cost, they will in general face an excess supply of labor, and so will find themselves rationing jobs. In this section we argue that the available evidence strongly suggests that the Ford Motor Company was paying more than the going wage for the type of labor it was attracting. This of course does not establish that Ford was paying efficiency wages rather than simply excessively high wages. In the next section, therefore, we consider the profit- and productivity- consequences of Ford's wage strategy and possible wage-productivity links.

The evidence that the five-dollar day represented a supra-competitive wage at least in 1914 and 1915 is overwhelming. We examine the question first by looking at the response of the external labor market to Ford's offer of high wages, and then by considering the response of those currently employed at Ford. As noted above, Ford did not have problems attracting labor even prior to doubling the wage it paid. The deteriorating labor market conditions in Detroit and its hinterlands meant that even with no wage increase, the length of the queues for Ford jobs would have been increasing in January of 1914, all other things equal. As would be expected, a doubling of the wage, even offered with a six month lag, had a large effect on the supply of labor to Ford.

Following the introduction of the five dollar day long queues for jobs were all too evident. The New York Iimes report on January 13, is typical of the reports that appeared almost daily for the two weeks after the inception of the five dollar day.

efficiency wage model. We discuss this further below. 40 Put more formally, efficiency wage theories have the implication that the constraint facing firms--that they provide workers with a reservation level of utility--does not bind. Eaton and White (1983) are particularly clear on this point. Note that it refers to the strategy of a single firm not the nature of market equilibrium. This is fortunate since our analysis is concerned only with Ford's strategy. 
Twelve thousand men, more than congregated around the plant on any day last week celebrated the [five dollar day] with a rush on the plant which resulted in a riot and turning of a fire hose on the crowd in weather but little different from zero... The crowd began forming at $100^{\prime}$ clock last night in spite of a blizzard. As a last resort at about 8 'oclock this morning the police got out the water hose...As soon as the job hunters had dried or changed their clothing they came back.

There is evidence that an excess supply of labor seeking jobs at Ford persisted even after workers gave up on lining up outside the plant gates. The Ford Archives contain a letter from the Ford legal department to the Sociological Department dated April 1915 indicating that two entrepreneurs who had charged large numbers of wouldbe Ford employees 50 cents or $\$ 1$ for writing letters of application to Ford had been induced to give up the practice. ${ }^{41}$ It is hard to see why Ford would object to this practice if it was actively seeking more workers. More telling perhaps is the observation that large numbers of workers migrated to Detroit in the hope of getting jobs at Ford. Eventually it proved necessary for Ford to make a rule that no worker would be hired who had not already lived in Detroit for six months.

Further evidence of the supra-competitive wages being offered at Ford comes from the reaction of other auto manufacturers in Detroit. The Detroit News of January 9 quotes the treasurer of one firm thus: "The Ford plant can only give employment to so many men and after that the others will have to seek employment in other plants at the prevailing wage. ${ }^{42}$ Nevins goes so far as to assert that the Ford plan benefitted all the automobile companies in Detroit by swelling the pool of available labor. (Even after it was announced that Ford would not hire workers from out of town, thousands continued to stream in to Detroit.)

The standard economist's response to evidence of this type is to suggest that the increase in wages was intended to improve the quality of the workers Ford was attracting. In this case, the apparent excess supply of labor would only have

41 Memorandum to J.R. Lee from H.R. Hartman, dated 4/30/15, Ford Archives Acc. 940, Box 16. 42 "Other Auto Men Say They Do Not Expect Plants To Be Affected," Detroit News, 
reflected the low skill levels of the workers applying, levels inferior to those of the workers actually engaged. This line of argument does not seem very relevant to the Ford experience. Ford made no effort to replace his workforce with new more highly skilled workers when he raised wages. Abell (1914) noted that

"The Ford Motor Company does not wish to change the present standard of labor in its plant. Three quarters of the employees are of foreign birth; a large number of them non-English speaking and of the grade ordinarily fitted for common labor.... The increment added to wages under the plan will not result therefore in the attraction of a higher grade of workmen and their substitution for the class at present employed."

Certainly everything we know about the technical change under way is consistent with this. Finally, if the goal were to attract better workers, it is hard to see why Ford would exclude workers from other cities from being hired.

The long queues for jobs at Ford seems to bely the view that the Ford high wage was merely a compensating differential (to the sort of people on the qeues) for unpleasant working conditions. 44 Furthermore, the behavior of workers within the plant casts serious doubt on the compensating differential explanation for the five dollar day. If it were correct, one would expect that the radical change in the conditions and wages package would not be to the taste of some workers who would then quit. On the other hand, if the change were simply towards an equilibrium where workers were paid more than their opportunity cost, one would expect to see the quit rate plummet.

In fact, as we discuss below, turnover declined precipitously after the introduction of the five-dollar day. Abell (1915) reports that the quit rate fell by 87 percent between March of 1913 and March of $1914 .^{45}$ A similar comparison is provided by Fisher (1917) who concludes that turnover fell from 400 to 23 percent

January 6, 1914 .

43Abell (1914) p.306

44 It might be argued that the queues were composed of workers who did not realize how unpleasant life was inside the Ford plant. Even granting this, an excess supply of labor was nevertheless readily available to Ford.

45 Abell (1915), p. 37. 
between the period October 1912-October 1913, and the subsequent year. ${ }^{46}$ slichter (1921) gives the figures 370 percent for calendar year 1913 and 54 percent for 1914.47

Anecdotal evidence on whether the five dollar day was necessary as a compensating differential appears conflicting. The experience of Charles Madison, a skilled mechanic who left the Dodge plant to work at Ford and then returned because he was "too fatigued after leaving the Ford factory to do any serious reading or attend a play or concert" seems atypical in more respects than just Madison's leisure tastes. ${ }^{48}$ Being a skilled mechanic, Madison was welcomed back to Dodge. 49 More insight into the situation at the Ford plant comes from the observation of Leslie McDonne11, a Ford worker who recalled that "It would almost have required the use of a rifle in order to separate the average Ford employee from the payrol1. 50,51

On balance, it seems fair to infer that the introduction of the five dollar day represented a decision to pay more than was necessary to attract workers. Indeed it is hard to see how a sudden doubling of wages paid given constant or deteriorating opportunity costs could possibly be explained in any otherway. Whether the five dollar day might reasonably, in retrospect, have been motivated by profit maximization is another matter. We turn next to the question of whether it was in fact, as Henry Ford claimed, "one of the finest cost cutting moves we ever maden .

IV. WAS THE FIVE DOLLAR DAY PROFITABLE? WHY?

46 Fisher (1917), P. 15.

47 Slichter (1921), p. 233.

48 Madison (1979/1980), op. cit.

49 The Dodge foreman was unsurprised to see him again.

50 McDonnel1, p.9.

51 A careful examination of the structure of the local labor market reveals the underlying consistency. See Raff (1986), Section 7. 
Some crude statistics on Ford Motor Company profits are given in Table 2. Profits rose steadily in both nominal and real terms in 1914 and 1915 . Recall that the out of pocket cost of the five-dollar day program was estimated to be $\$ 10$ million for a year in which total profits were forecast at only $\$ 20$ million.

Where did the money come from? Two contemporaries discussed Ford productivity quite explicitly. Abell writing in Iron Age appears detatched though obviously very impressed by the Ford experiment. His article begins by asserting that:

Conditions in industry could hardly have provided a more severe test for profit sharing plans than they have undergone for the past year. Distributions to employees have been suspended by some of those organizations commonly accepted as the leaders in successful management. By way of contrast the comparative financial statement of the Ford Motor Company as of September 30,1913 ang September 30, 1914 is a strikingly interesting and significant document. 52

Abell provides an estimate of the productivity gains resulting from the five dollar day as well. He concludes on the basis of Ford's testimony before the Industrial Relations Commissions that between 1913 and 1914 the Ford company produced 15 percent more cars per day, with 2000, or about 14 percent, fewer workers and a reduction in the number of hours worked per worker. This figure understates the productivity increment because new production techniques raised significantly the share of Ford value added in each car by manufacturing several car parts that had previously been purchased from other suppliers. Even without taking any account of the increase in Ford value added or the reduction in hours per day, his figures suggest close to a 30 percent productivity increment. Lee is said to have calculated that Ford plan raised wages by 105 percent, but labor costs by only 35 perent, implying about a fifty percent improvement in productivity. ${ }^{53}$ It is not clear that this calculation took account of the increase in value added per car that occurred in 1914 .

52 Abe11 (1915), pp. 33, 36.

53 Nevins, p. 548 . 
TABLE 2

Ford Motor Company Net Income 1910-1915

Year

1910

1911

1912

1913

1914

1915

\section{Nominal}

$4,163,451$

$7,338,588$

$13,542,678$

$27,087,204$

$31,757,769$

$40,307,167$
Rea1 ( $\$ 1910)$

$$
\begin{array}{r}
4,163,451 \\
7,413,464 \\
13,139,301 \\
26,452,347 \\
30,419,318 \\
36,901,187
\end{array}
$$

Source; Nevins (1954), p. 647. The 1914 and 1915 figures have been adjusted to put them, like the others, on a calendar year basis. (The real values use the GNP deflator from Historical Statistics of the United States, p. 224.) 
These estimates are confirmed by the available quantitative information.

Table 3 presents some information drawn from the Ford archives on the cost of making model $T$ chassis. Despite the drastic increase in the wages Ford paid, total costs actually declined between December 1913 and December 1914, even fully counting allocated overhead. The sharp decline in the costs of materials corroborates suggestion made above that the fraction of value added generated inside the Ford plant was increased in 1913.

Similar detailed data are not available on the costs of other components of Ford cars. But the productivity question can be addressed crudely using aggregate data. To isolate any increment in productivity following the introduction of the five dollar day in January of 1914, we estimated multiple regressions relating the log of productivty (measured alternatively using total labor hours and total production labor hours in the denominator) on seasonal dummies, a time trend, and alternatively dumies for 1914 and 1914 and 1915. The results displayed in Table 4 suggest a substantial productivity increment of between 40 and 70 percent following the introduction of the five-dollar day. These figures are probably underestimates given that no account is taken of the increased share of value added that was generated inside the Ford plant.

An alternative and somewhat independent way of looking at the impact of the five dollar day on productivity is to consider its impact on prices. If it represented a substantial cost increase, one would expect to see an abnormal increase in price and reduction in profits at its inception. Table 5 presents some information on prices. It is clear that prices continued their downward trend in 1914 at about the same pace that typified the 1910-1920 period. As we have already observed, profits performed reasonably well despite falling prices. 
TABLE 3

\section{Some Monthly Cost Figures for the Model $T$ Chassis}

$$
1913-1915
$$

Date
December 1913
March 1914
June 1914
September 1914
December 1914

\section{Materials}

122.23

105.07

106.29

94.69

99.28
Labor

17.03

23.54

26.18

25.86

24.39
Overhead

$$
\begin{aligned}
& 22.66 \\
& 31.40 \\
& 34.94 \\
& 34.54 \\
& 32.52
\end{aligned}
$$

Source: Ford Archives Accession 125 (Model T Cost Books). 
TABLE 4

\title{
Impact of the Five-Dollar Day on Productivity
}

\author{
$\log$ of \\ Output per \\ Time \\ Period \\ Production \\ Workers
Log of Output per Total Workers \\ 1914 \\ .655 \\ (.164) \\ .528 \\ $(.177)$ \\ $1914-1915$ \\ .530
$(.155)$ \\ .414 \\ (.166) \\ Estimates are based on regression equations including seasonal
dummies and a time trend. Standard errors are given in
parentheses. \\ Regression data source: Ford Archives Accession 922.
}


TABLE 5

\section{Model T Prices}

Year

1910

1911

1912

1913

1914

1915

1916

1917

1918

1919

1920

1921

\section{Nomina 1 \\ Price}

\section{$\$ 950$}

780

690

600

550

490

440

360

450

525

507

397
Real Price

(S 1910)

950.0

787.9

669.4

585.9

526.8

448.6

359.3

236.7

263.1

269.0

227.9

214.0

Source: Ford (1922), p. 145. Price deflator is from Historical Statistics of the United States, p. 224. 
We are therefore driven to the question of whether the five-dollar day itself caused the productivity improvements or merely coincided with the introduction of productivity enhancing technologies. In order to answer this question, we examine possible mechanisms through which wage increases may have directly increased productivity.

The historical details of technical change closes off interest in efficiency wage theories based on selection considerations. These theories hold that the point of the high wages is to encourage more highy skilled (and so more productive) individuals, the higher opportunity cost of whose time would certainly be known to them, to select themselves to apply for jobs. But the industrial journalists Arnold and Faurote, writing about the Ford factory around this time for a technical audience, record very different needs.

As to machinists, old-time all-around men, perish the thought! The Ford Company has no use for experience in the working ranks, in any way. It desires and prefers machine tool operators who have nothing to unlearn, who have no theories of correct surface speeds for finishing, and who will simply go what they are told to do, over and over again, from bell-time to bell-time.

To a first approximation, the company didn't want skilled workers. It would therefore hardly have been willing to actually pay to find them. Ford engineers were de-skilling the jobs. 55

A second theory has increased wages increasing productivity by reducing turnover costs. We have noted that prior to the five-dollar day, turnover rates at Ford had reached dramatic heights and that they subsequently declined very sharply. Table 6 presents the only detailed information which is available for particular months. 56 There are difficulties in judging just how much of the drastic decline

54 Arnold and Faurote (1915), pp. 41-42.

55 For a historical narrative, see Hounshell (1915), pp. 217-262. For some statistics, see Meyer (1981), pp. 48, 50, and 51.

56 It is clear that there was once much more. But our archival searches have not, as yet, turned any of it up. We suspect it simply has not survived. 
TABLE 6

Separations from the Ford Motor Company for Selected Months

$\underline{1912-1914}$

$\begin{array}{lccc}\text { Date } & \text { Five-day Men } & \text { Discharges } & \text { Quits } \\ \text { December } 1912 & 3,594 & 176 & 386 \\ \text { March } 1913 & 5,156 & 1,276 & 870 \\ \text { October } 1913 & 322 & 137 & 326 \\ \text { March } 1914 & 166 & 166 & 115\end{array}$

Source: Abe11 (1914), P. 49, and Ford (1916).

TABLE 7

Annual Turnover Rates 1913-1915

$1913 \quad 1914 \quad \underline{1915}$

$\begin{array}{lrrr}\begin{array}{l}\text { Average force } \\ \text { employed }\end{array} & 13,623 & 12,115 & 18,028 \\ \text { Total leaving } & 50,448 & 6,508 & 2,931 \\ \text { Turnover rate } & 3708 & 548 & 168 \\ \text { Resignations } & 39,575 & 5,199 & 2,871 \\ \text { Lay-offs } & 2,383 & 385 & 23 \\ \text { Discharges } & 8,490 & 926 & 27\end{array}$

Source: Slichter (1921), p. 244.

TABLE 8

\section{Absenteeism}

Tota 1

Date

October 6, 1913

October 6, 1914
Workers

12,548

12,645
Number

Absent

1,250

311
Percent Absent

108

2.58

Source: Abe11(1915), p. 37 . 
between 1913 and 1914 in turnover can be attributed to the effects of the fivedollar day. As we noted above, the extent to which the reforms of October 1913 solved the turnover problem prior to the advent of the five-dollar day, is unclear. Moreover the sharp economic downturn which had hit Detroit's hinterlands by late 1913 and was afficting the city itself by late springtime would have substantially reduced turnover even if wages had not been increased. Raff (1986) argues that this effect alone may have accounted for up to half of the decline in turnover between 1913 and 1914.

But there is a more troublesome problem with this explanation than these timing issues. Payments to the duly qualified workers did rise radically with the advent of the five-dollar day. For the five-dollar day to be rationalizable on grounds of reduced turnover, however, it is necessary that the cost to firms of turnover was considerably reduced. In order to make a crude assessment of the savings, we begin with an expression for the user cost of labor.

$$
c=w+(i+q) T
$$

where $w$ is the wage, 1 the relevant interest rate, $q$ the turnover rate, and $T$ training costs. The crucial question is whether the decline in $q$ assoclated with the five-dollar day made the second term shrink enough to reduce the total user cost on balance.

It is instructive to insert some plausible values into the formula for the user cost of labor. Since we have $w$ on a daily basic, we want $i$ and $q$ on a daily basis. On a daily basis, any reasonably annual 1 is zero. Putting annual turnover rates for 1913 and 1914 (which we do possess: see Table 7) on a daily basis, the cyclically adjusted change in $q$ is .52 percent. The calculation then turns on the size of T. Raff (1986) examines contemporary calculations of the training and breaking-in costs of various grades of labor and a Ford plant survey of training times conducted (with reference to essentially the same production process) in 1917. 
He concludes that setting $T$ equal to a week's pay (i.e. $\$ 30$ ) is somewhere between accurate and generous.

Assuming a value of $\$ 30$ for the turnover cost, one then calculates that reduced turnover saved the firms about $\$ 0.16$ per day. Even allowing for the fact after a time workers did not earn the five dollar day until six months after they started, and that some workers were for one reason or another ineligible for it, it is difficult to conclude that more than about 6 percent of the cost of the five dollar day program was offset by increased wages. Even the most favorable of the pairs of turnover numbers in Table 6 yields only 19 percent. These are very small fractions.

This calculation does however presume that the relevant turnover costs are simply training costs. It is very plausible that turnover imposed costs other than training new workers. First, turnover largely took the form of workers not showing up for work and then after five days being declared to have quit. Presumably with high turnover, firms were very unsure of their staffing needs and so frequently found themself either shorthanded or with redundant workers. Second, in a highly fluid environment, it may well have been the case that more than one worker had to change jobs for each person who left. In this case, a single departure could require training costs to be borne a number of times. Third, when departure was associated with dissatisfaction, it may well have involved a negative impact on the productivity of others. Sabotage is only an extreme example. Overt conflict with foremen which was very common is another.

A third alternative explanation for how a wage increase might raise productivity is that higher wages might elicit increased effort. Suppose effort is verifiable only at some cost. If wages are set at a level at which there is a utility cost to losing a job, workers will autonomously choose to work harder: high wages will substitute for monitoring and control. 
There is ample evidence that workers worked harder after the introduction of the five dollar day. Table 8 shows a pronounced fall in absenteeism, for example. Even more dramatic reductions in discharges appear to have been realized. Abell (1915) reports that discharges declined by 90 percent between March of 1913 and 1914, while Lee (1916) notes that there was only one discharge at Ford in the early part of 1916. The decline in discharges may well reflect both altered personnel policies (both the company trying to keep its employees and the company having figured out ways to make those it had given up on decide to leave without being fired) and the improvement in employee performance to be associated with increased cost of job loss. 57

It is difficult to gauge the impact of these changes on productivity. They are probably best thought of as visible manifestations of less easily quantified changes in workers' behavior. Certainly, there is ample anecdotal evidence that work habits in the Ford plant changed drastically following the introduction of the five dollar day. Klann, a production foreman at the time, describes the change in the company's labor strategy simply: "[They] called us in and said that since the workers were getting twice the wages, [the management] wanted twice as much work. On the assembly lines, we just simply turned up the speed of the lines." 58 Harold Slausen (1917), a journalist reviewing the Ford experience, concluded that:

But as much as the monotony of each man's work might be expected to lead to discontent the prospect of wages double those that could be obtained in any other factory for the same work ggrves as a deterrent and positions in the Ford factory are eagerly sought for.

Arnold and Faurote described the results of Ford's strategy when they wrote:

The Ford high wage does away with all of this inertia and living force resistance. The workingman are absolutely docile, and it is safe to say that since the last day of 1912 , every single day has seen marked reductions in the Ford shops labor costs.

57 On ways the company found to induce employees to quit, see, e.g., Bondie, p. 11. 58 Klann, p. 84.

59 Slausen (1917), p. 263. 
A difficulty with the effort elicitation efficiency wage explanation for the productivity increase within the Ford plant, is that many of the kinds of malfeasance Ford sought to control were probably easy to monitor. Absenteeism is only the most obvious example. The coming of the assembly line must have made monitoring workers' speed easier. ${ }^{61}$ Increased ease of monitoring might be expected, on the efficiency wage theories, to lead to decreased rather than increased wages. On the other hand, it is apparent from Mathewson's (1931) classic work that in automobile production there was very substantial scope--even for the workers with highly routinized jobs--to collude and restrict output. ${ }^{62}$

More importantly, the cost to Ford of any shirking by workers was increasing sharply, given the increasingly interdependent character of production. More intensive use of fixed and quasi-fixed factors through smooth co-ordination of work flows (or, more abstractly, through dedicated, Model T-specific physical and human capital) was the real source of the profits. It is revealing in this regard that in addition to influencing worker through the use of the assembly line and sharply increasing wages, Ford also increased the relative number of supervisors in. his plant drastically between 1913 and 1915.63 This suggests that the increased cost, and risk, of shirking following the routinization and the introduction of the assembly line was a more important consideration than the automatic monitoring these mechanical innovations provided. 64

The question of co-operation raised in the preceding paragraphs brings us finally to what might be called "morale based" efficiency wage theories such as the one proposed by Akerlof (1982). Morale explanations in general, and Akerlof's gift

60 Arnold and Faurote (1915), p. 331.

61 Raff (1986), Section 6.

62 See Mathewson (1931). The passages on pp. 21-22 and p. 125 deal explicitly with assembly lines, but there are many other cogent passages--see p. 61 in particular. 63 Meyer (1981), p. 56. 64 On all of this, and in particular on the sense of risk as well as cost, see Raff (1986), Section 9 . 
exchanges in particular, have received relatively little attention compared to other efficiency wage theories. But it is quite plausible that the higher wages might have raised morale and contributed to the Ford plant's productivity.

The Ford shops were certainly no Workers' Paradise in 1914. The Company proudly claimed that it crowded workers and machines together extraordinarily tightly to take advantage of every available inch of space on the shopfloor. It even filled the air with work-in-progress. There was no particular dignity in work at the plant. Thus there was ample scope for Ford to raise morale. And the changing technology increased the importance to Ford of "buying the peace" and avoiding systematic soldiering and output restriction or other collective action by his workforce.

The company coupled wage increases with explicit concern with its workers' sense of dignity. And there is evidence to suggest that the employees were quite pleased with their new lot. There were many Ford clubs and societies. Nevins remarks that workers wore their numbered Company ID badges with pride to dances and other social events. In contemporary Detroit, these otherwise raw immigrants must nevertheless have seemed, in the ethnic shantytowns, men of substance. The company even tried to help them become citizens and encouraged them to vote.

Other aspects of the Ford program besides the wage increase also can be seen as directed at potential morale problems and their consequences. For the character investigations of the Sociological Department were not its only activity. Its English classes, with their lessons oriented self-consciously towards "American" home life, a high school civics-style picture of American history, government, and democracy, and, most strikingly, the general subjects of industrial efficiency and labor relations, appear in retrospect as much an elaborate exercise in forming workers' attitudes as a program of language training. ${ }^{65}$ It is also plausible that 
in the context of the costs of malfeasance being more easily imposed by large groups than by individuals, the company may have been tacitly bargaining with workers in its wage setting policies rather than just responding to a fixed reaction function. Rent-sharing was going on in a context in which history and beliefs (as distinct from preferences) mattered. These two considerations, which to some extent stand outside the established corpus of efficiency wage theory, even of the mixed shirking-morale variety, are developed in detail in Raff (1986).

On balance it seems fair to conclude that Ford was able, by offering the five dollar day, to reduce the turnover among his workers and to extract much more intensive, and generally productive, effort from them. These developments complemented the revolution in the production process, and so in work content, which Ford was bringing about. They allowed him to realize that revolution's full commercial value.

\section{v. CONCLUSIONS}

Henry Ford's five dollar day arose at least in part out of concern about turnover and poor worker morale and their consequences for productivity. Ford's wage surely exceeded his workers' opportunity cost and put him in the position of rationing jobs. The increased wages did yield substantial productivity benefits and profits.

A natural question raised by this study is the extent to which other firms emulated Ford. To the extent that they did, some evidence for the efficiency wage interpretation of Ford's actions is provided. While it is obvious that sudden doublings of wages did not become common even after Ford's actions, there is evidence that Ford's actions did affect wage patterns. Rae (1965) in his history of 
the automobile industry concludes that as other firms eventually introduced Ford's technologies, they emulated his high wage policies By 1928, before the UAW had become an important factor in the automobile industry, wages were almost 40 percent greater than in the rest of manufacturing. 66

In future research it would be useful to examine the wage-productivity nexus at other firms as well. This would also permit a judgement about the breadth of the relevance of our findings. The Ford Motor Company was dedicated to manufacturing as few companies in the contemporary American economy can be. The overwhelming majority of its staff were actually working on production. A pessimist would conclude that the dramatic technological developments in the Ford plant make it extremely atypical. An optimist would say that if one could find evidence here, there is real promise in so much less routinized a collection of enterprises as the American macroeconomy today.

Raff (1986).

66 Rae (1965) p. 127. See also Brissendon (1929) pp. 96-97. 


\section{REFERENCES}

0. J. Abell, "The Ford Plan for Employees' Betterment," Iron Age (January 8, 1914) $307-308$

1915) $33-41$ and 56

G. A. Akerlof, "Labor Contracts as Partial Gift Exchange," 97 Quarterly Journal of Econonics (November, 1982) 543-569

H. M. Arnold and F. L. Faurote, Ford Methods and Ford Shops (New York, 1915)

A. Bondie, Reminiscences, unpublished typescript in the Ford Archives in Dearborn, Michigan

P. F. Brissenden, Earnings of Factory Workers 1899-1927 (Washington, 1929)

G. Brown, Reminiscences, unpublished typescript in the Ford Archives in Dearborn, Michigan

J. Bulow and L. Summers, "A Theory of Dual Labor Markets with Application to Industrial Policy, Discrimination, and Keynesian Unemployment," 4 Journal of Labor Economics (1986) $376-414$

L. Carmichael, "Can Unemployment Be Involuntary: Comment," 75 American Economic Review (December, 1985) 1213-1214

A. D. Chandler, Jr., The Visible Hand: The Managerial Revolution in American Business (Cambridge, 1977)

A. D. Chandler, Jr., ed., Giant Enterprise: Ford, General Motors, and the Automobile Industry (New York, 1964)

R. C. Clark, Corporate Law (Boston, 1986)

F. H. Colvin, "Building an Automobile Every 40 seconds," 38 American Machinist (May 8, 1913) $757-762$

J. R. Commons. Labor and Administration (New York, 1923)

R. Conot, American Odyssey (New York, 1974)

W. Dickens and L. Katz, "Inter-Industry Wage Differentials and Theories of Wage Determination," unpublished manuscript

B: C. Eaton and White, "The Economy of High Wages: An Agency Problem," 50 Economica (Apri1, 1983) 175-181

B. Fisher, "Methods of Reducing the Labor Turnover," Bulletin of the Bureau of Labor Statistics No. 196 (1917) 15-24

H. Ford "Testimony of Mr. Henry Ford," in Industrial Relations: Final Report 
and Testimony Subnitted to Congress by the Commission on Industrial Relations Vol. VII (Washington, 1916) 7626-7638

..... (with the assistance of S. Crowther), My Life and Work (New York, 1922)

L. Garrity, "The Story of the Poor Commission of Detroit 1880-1918," unpublished Wayne State University M.A. thesis.

G. Heliker, "Labor in Detroit: 1900-1916," unpublished typescript in the Ford Archives in Dearborn, Michigan

D. A. Hounshe11, Fron the American Systen to Mass Production: The Development of Manufacturing Technology in the United States (Baltimore, 1984)

L. F. Katz, "Efficiency Wage Theories: A Partial Evaluation," in S. Fischer, ed., NBER Macroeconomics Anmual (Cambridge, 1986)

W. Klann, Reniniscences, unpublished typescript in the Ford Archives in Dearborn, Michigan

A. Krueger and L. Summers, "Efficiency Wages and the Inter-Industry Wage Structure," unpublished paper

J. R. Lee, "The So-Called Profit-Sharing System in the Ford Plants," 65 Annals of the American Association of Political and Social Sciences (1916)

D. Lewis, The Public Image of Henry Ford: An American Folk Hero and His Company (Detroit, 1974) $(1980 / 1981)$

C. Madison, "My Seven Years of Auto Slavery," 19/20 Michigan Quarterly Review

L. McDonnel1, Reminiscenses (0. Barrule, Life with Uncle Henry), typescript in the Ford Archives in Dearborn, Michigan

S.S. Marquis, "The Ford Idea in Education, " in National Education Association, 64 Addresses and Proceedings ... 1916 (1916) 910-917 1931)

S. B. Mathewson, Restriction of Output Among Onorganized Workers (New York,

S. Meyer, The Five Dollar Day: Labor Management and Social control in the Ford motor Company 1908-1921 (Albany, 1981)

D. Montgomery, Workers Control in Anerica: Studies in the History of Work, Technology, and Labor Struggles (New York, 1979)

(Motor Age), "Ford Jobs in Great Demand in Detroit," 25 Motor Age (January 15, 1914), p. 34 .

A. Nevins, Ford: The Times, the Man, and the Company (New York, 1954)

H. F. Porter, "Giving the Men a Share: What It's Doing For Ford," 31 System (March, 1917) 262-270 
J. B. Rae, The Anerican Automobile: A Brief History (Chicago, 1965)

D. M. G. Raff, "Wage Determination Theory and the Five Dollar Day at Ford: A Detailed Examination, " unpublished monograph

P. Roberts, English for Coming Americans: First Reader and Second Reader (New York, 1912)

W. H. Sewe11, Jr., Work and Revolution in France: The Language of Labor from the Old Regine to 1848 (New York, 1980)

C. Shapiro and J. E. Stiglitz, "Can Unemployment Be Involuntary: Reply," 75 American Econonic Review (December , 1985) 1215-1217

H. W. Slausen, "A Ten Million Dollar Efficiency Plan," Machinery (October, 1914) 83-87

S. Slichter, "The Management of Labor," 27 Journal of Political Economy (December, 1919)

S. Slichter, Turnover of Factory Labor (New York, 1921)

J. E. Stiglitz "Theories of Wage Rigidity," National Bureau of Economic Research Working Paper No. 1442 (1984)

U.S. Department of Commerce, Historical Statistics of the United States: Colonial Times to 1970 (Washington, 1975) 